\title{
Water Regime and the Direction of Drainage of Phreatic Aquifer in the Bačka Loess Plateau
}

\section{Dragoslav Pavić, Lazar Lazić, Živan Bogdanović, Jovan Plavša'}

\begin{abstract}
Phreatic aquifer belongs to the type of normal aquifers. It is the shallowest water horizon which most often appears in the sediments of intergranular porousness which characterizes the formations sedimented on the territory of Bačke during the Quartar. Due to the permanent presence of Quartar sediments on the top of the geological pillar of the entire Bačka loess plateau, the phreatic aquifer has a continuous distribution within the entire investigated area. In this paper, the main emphasis has been given to the determination of the scope of influence of the dominant factors on the water regime of the phreatic aquifer of the Bačka loess plateau, then the determination of its basic characteristics and types of regime, as well as the general direction of the drainage.
\end{abstract}

Key words: phreatic aquifer, Bačka loess plateau, water regime
Department of Geography, Tourism and Hotel Management, University of Novi Sad, Trg Dositeja Obradovića 3, 21000 Novi Sad, Serbia and Montenegro

\section{Introduction}

The distribution of the phreatic aquifer and main characteristics of its regime are related to a number of very complex and interdependent phenomena and processes whose character has been defined by numerous factors among which the most important would be hydrological, pedological and geomorphological conditions, and especially the way, type and quantity of input, as well as of the output of water. The fluctuations of the water-table of the primary aquifer is, above all, a result of unsteady input and output of water, which is directly dependent of the uneven distribution of precipitation and the dominant temperatures of air and soil, i.e. the quantity of evaporation. Apart from the vertical component of the flow, and because of the relief conditions, there is also a horizontal movement of the phreatic aquifer from the high water-tables of the absolute height of the phreatic water-table to the low levels.

The basic aim of this paper has established major characteristics of the water regime and the direction of the output of the phreatic aquifer of the Bačka loess plateau, as well as putting them into cause-result relation with the factors that characterise them.

\section{Geographic position and borderlines of the investigated area}

The Bačka loess plateau is situated to the far north of Serbia, or north-western part of AP Vojvodina. It covers the central and at the same time largest part of northern half of Bačka (Map 1). Its southern and southwestern part has often been called Telečka in written studies, and its eastern part has been called Gornji breg or Žuti breg (Bukurov, 1975).

The southern border of the Bačka loess plateau partly consists of the transitional loess and sandy area towards the Subotica sandy plain, and the other part is the borderline towards the neighbouring country - Hungary. If we start from the east, the northern border starts a bit further to

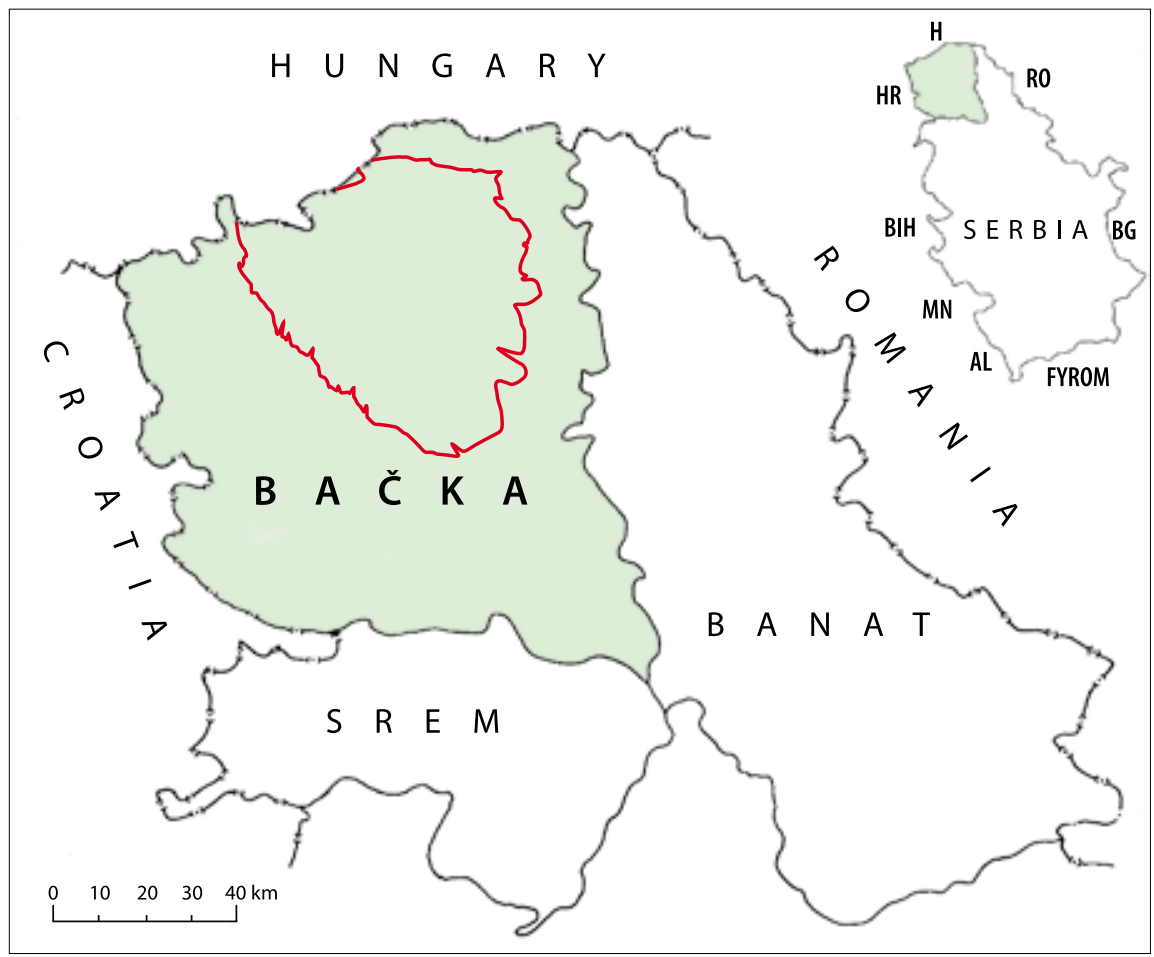

Map 1 The geographical position of the Bačka loess plateau 
the east from Lake Ludas, more precisely on the level of the elbow-shaped meander of the river Keres. Further up to the west it goes along the line which connects the settlements of Stare Torine, Šupljak, Masarikovo and Palić, and then it continues towards Subotica after which it sharply turns to the north-east, i.e. towards Kelebija Lake, at which point it comes out to the state border. Furthermore, almost up to Riđice, the Bačka loess plateau to the north of our country is mainly framed by the state borderline. Only near the settlements of Ljutovo, Donji and Gornji Tavankut, the northern borderline of this relief entity is again represented by the loess and sandy area towards a smaller patch of sandy area of the mentioned settlements, where it goes into the territory of Serbia.

To the east, south, south-west and west, the borderline of the plateau is mostly welldefined. It consists of a continuous borderline, along which the plateau is elevated above the lowland terrain of the Bačka pleistocene terrace in the form of rifts and downslopes of different incline from 10 to $30 \mathrm{~m}$. On the mentioned contact point of the morphological entities, a lot of settlements have been built, such as: Velebit, Trešnjevac, Gornji Breg, Srbobran, Vrbas, Kula, Crvenka, Sivac, Kljajićevo, Svetozar Miletić, Stanišić and Riđica. In the given borderline, the total area of the Bačka loess plateau is $2,800 \mathrm{~km}^{2}$.

\section{Materials and research methods}

The data about the observations of the depth of the primary aquifer have been used as basis material for the analysis of water regime of the phreatic aquifer of the Bačka loess plateau. The data have been taken from Dnevnik osmatranja dubine freatske izdani u Vojvodini (The Observation Diary of the Phreatic Aquifer in Vojvodina) which is part of the documentation of the Public Hydrology Company "Vode Vojvodine". A systematic observation of the depth of the phreatic aquifer on the territory of Vojvodina started in 1951. Only on the territory of Bačka, over 430 measuring wells were established. However, in the following few years, the observations were not carried regularly in a number of wells, whereas some other wells stopped functioning completely. This is the reason why we have taken the observation period from 1951 to 1980 as the most representative one for which, within the borderline of the observed area, there exist complete data about the depth of the phreatic aquifer in the 13 wells (Map 2). At the same time, in this paper we have used the data about the air temperatures and precipitation of the meteorological stations of Palić and Vrbas, as well as the rich cartographic material and reference resources.

Observing the applied methodological approach, it is important to empha-

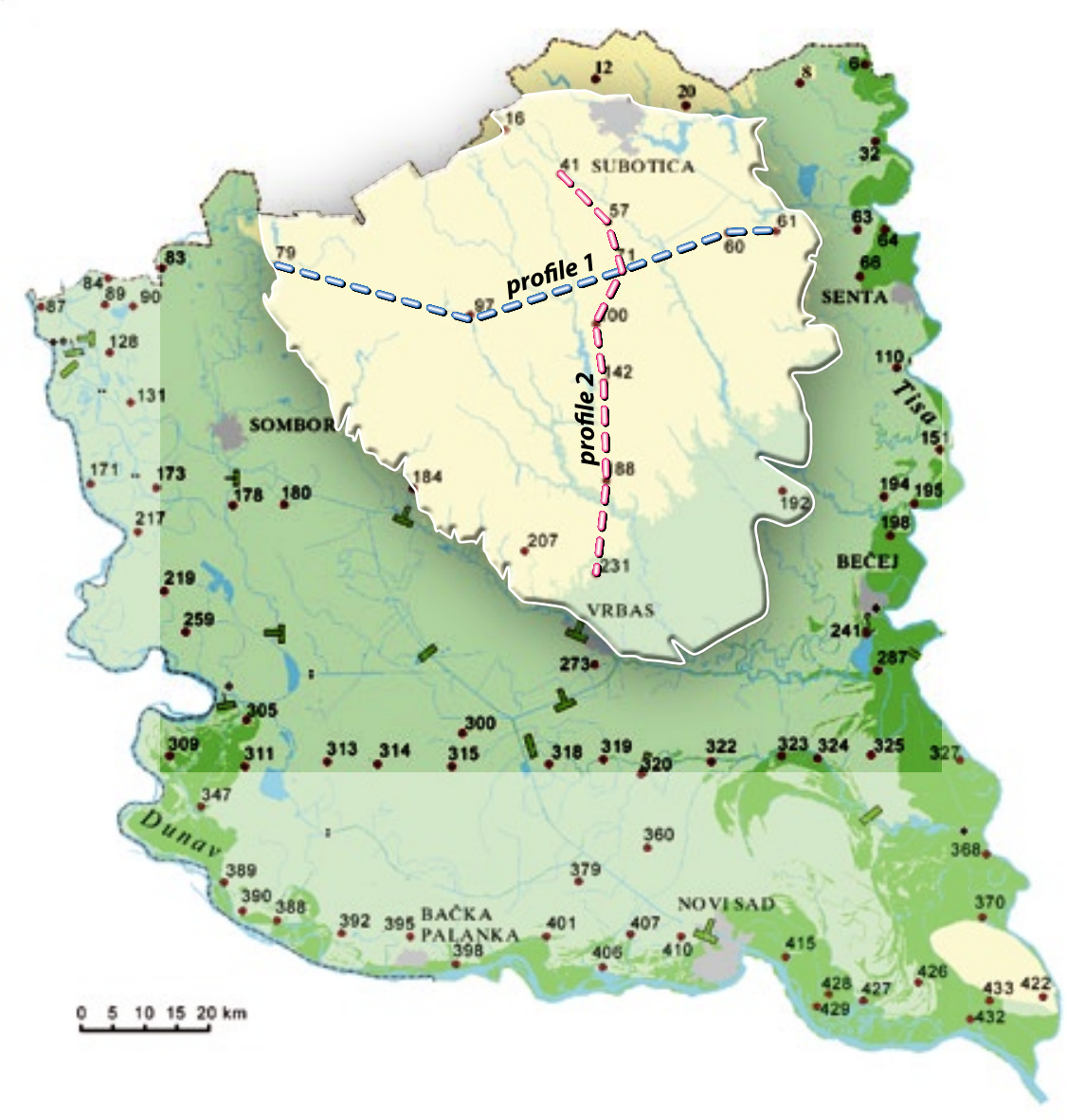

Map 2 Position of the analysed wells and profiles

size that in the first half of the paper we discuss the scope of the influence of the dominant factors - relief and climate conditions, above all, relevant to the regime of the phreatic aquifer in the investigated area. Namely, this is the analysis of the influence of the height of the topographic area on the depth of the phreatic aquifer which is performed by the comparison of the absolute height of the terrain where there is the measuring well with the average annual phreatic water-table for the observed well. The influence of the relief on the phreatic regime has been also investigated through the establishment of the dependency of the variability of the phreatic water-table in relation to the height of the topographic area. Finding out proofs for the above-mentioned dependency relation has been done through the comparison of the amplitude of the phreatic water-table for the measuring wells situated on different absolute heights.

The observation of the influence of climate conditions on the phreatic regime of the investigated area has been done through the comparison of the average monthly values of the water balance climate factors with the average monthly phreatic water-tables of the chosen wells. The water balance of the climate factors represents the difference between the total precipitation and evapotranspiration which was, in this case, calculated by the Türc formula for the meteor- ological stations Palić and Vrbas. The Türc formula is as follows:

$E T P=0.40 \times t \div(t+15) \times\left(J_{g}+50\right)$

ETP - evapotranspiration for the given month

$\mathrm{t}$ - average monthly air temperature $\left({ }^{\circ} \mathrm{C}\right)$

$\mathrm{J}_{\mathrm{g}}$ - intensity of sun radiation ${ }^{1}\left(\mathrm{gr} \mathrm{cal} / \mathrm{cm}^{2}\right)$

The main aim of the second part of the paper is the observation of the main characteristics of the regime, its typification, as well as the establishment of the direction of the output of the phreatic aquifer. During the analysis of the data related to the phreatic water-table, its relation to the topographic area and annual fluctuation of the water balance of the climate factors, a standard graphic and statistical method has been used.

\section{Discussion of the results}

\section{The influence of the dominant factors on the phreatic water regime}

On the territory of the Bačka loess plateau, the dominant factors which determine the main characteristics of the phreatic water regime are relief and climate conditions. However, before comprising the scope of influence of these factors on the phreatic regime,

Data given by Katić et al. (1979) 
it is important to emphasize that hydrologi$\mathrm{cal}$, as well as pedological circumstances are extremely favourable from the point of view of the formation and input of the phreatic water horizon. Namely, for the purpose of the geological pillar of the total Bačka loess plateau, there are early quartar sediments which form the water collecting environment for the phreatic water. Because of such hydrogeological circumstances this phreatic form has a countinuous spreading capacity across the entire investigated area. After the analysis of the conditions of the water input of the phreatic aquifer, the most important factor is the soil. The most dominant type of soil on the plateau is carbonated cernozem which, due to its mechanical composition, has good filtration capacity positively influencing the input of the phreatic area with atmospheric water.

Geomorphologically, the Bačka loess plateau represents a wide, mildly domed elevation whose heights are declining from the north and northwestern parts to the west, south and east. Its absolute heights are towards north, in the surroundings of Subotica $(110-125 \mathrm{~m})$, an its lower parts are to the south near Srbobran (9om). The area of this relief entity is not completely flat but rather rolling. B. Bukurov (1975) distinguished the following forms in its relief: dine (dunes), interkolinske depresije (depressions), dolove (valleys) and plavine (flood plains).

To a large extent, the relief distinguishes the depth and the direction of the output of the phreatic aquifer as imortant determiners of its regime. The free water-table of the phreatic aquifer usually follows the hipsometric relations on the topographic area. This means that with an increase in height there is an increase in the phreatic water-table, whereas when it decreases it is in accordance with the decrease in height of the topographic area (Marković and Bogdanović, 1995). The above-mentioned rule on the example of Bačka loess plateau can be proven by the analysis of two simplified profiles which show the interdependency of the height of the terrain and the average annual water-tables of the phreatic aquifer (Map 2).

Generally, in the directon west - east, the profile line 1 intersects the entire territory of the Bačka loess plateau (Graph 1). Analysing the profile, we can see that in its largest part the phreatic water-table generally follows the hipsometric changes in the relief. The aberration from the mentioned regularity exists only in the area between the wells 71 and 60 , where the height of the phreatic water mildly decreases, whereas the height of the topographic area noticeably increases. This is a result of the fact that the well 71 is on the rim of the valley of Čika which has, by its intersection into the topographic area, partly disturbed the ten-

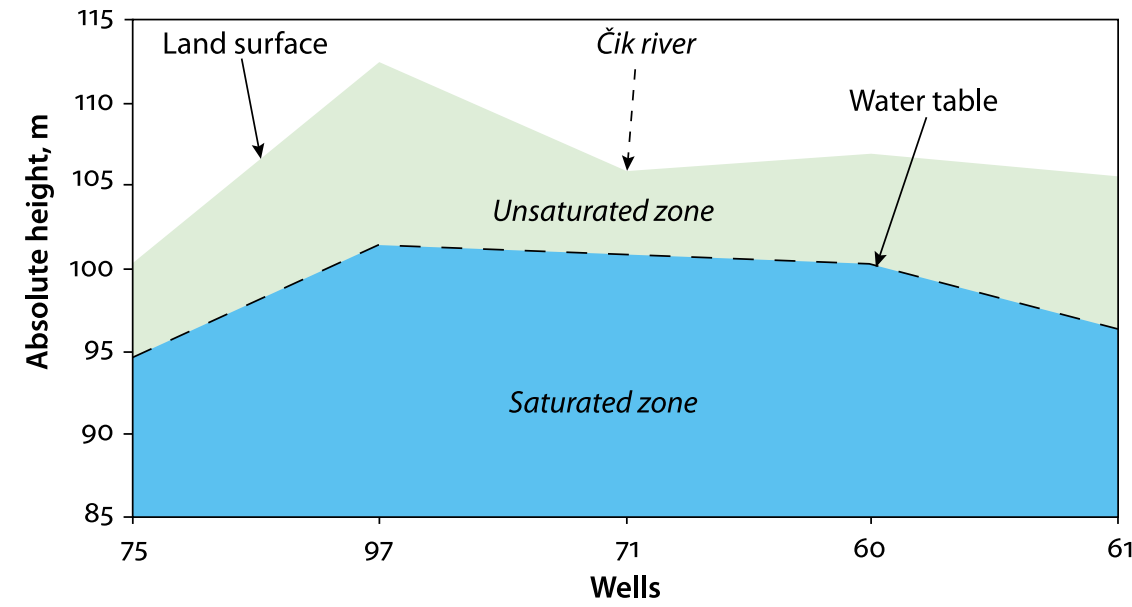

Graph 1 The relation of the topographic area and the average annual phreatic watertable for the period 1951-1980 on the profile 1: Stanišić - Pačir - Žednik - Senćanski Trešnjevac

dency of the steady decrease of the height of the terrain from the well 97 to the well 61 , which is not the case with the phreatic water-table.

On the observed profile the highest average annual depth of $11.07 \mathrm{~m}$ of the phreatic aquifer has been observed in the highest well $97(112.46 \mathrm{~m})$, and the smallest of 4.90 $\mathrm{m}$, in the valley of Čik in the well 71 (105.96 $\mathrm{m})$. The average annual phreatic water-table is also the highest in the well 97 (101.39 m) from which point it steadily decreases to the west and east, which shows the general direction of the phreatic output.

The profile line 2, of the general direction north-south, goes through the central area of the plateau (Graph 2). On the entire analysed profile the phreatic water-table follows the height relations of the topographic area. Out of the total of seven observed wells, the highest average annual depth of $8.57 \mathrm{~m}$ of phreatic aquifer has been observed in the well 41 , which is situated on the highest absolute height (121.74 $\mathrm{m})$, whereas the phreatic aquifer is the shallowest on the rim of the mentioned valley of Čik, i.e. in the well 71 where it is $4.90 \mathrm{~m}$.

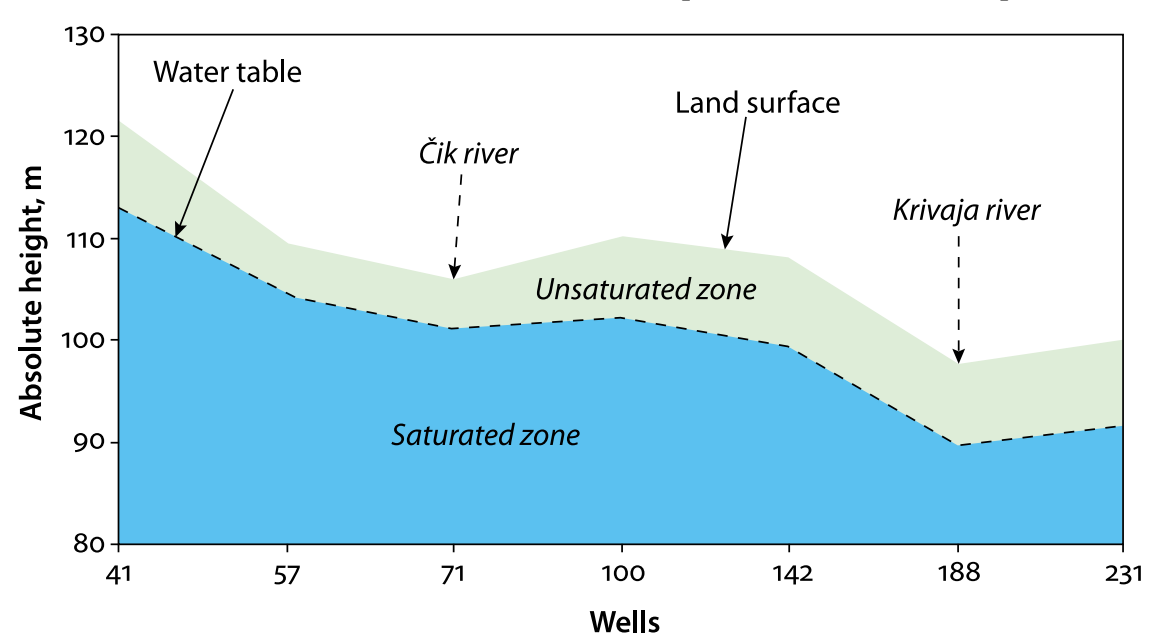

Graph 2 The relation of the topographic area and the average annual phreatic watertable for the period 1951-1980. on the profile 2: Mala Bosna - Žednik - Mali Beograd

- Bačka Topola - Mali Iđoš - Feketić

The highest average annual water-table of phreatic aquifer is in the well 41 (113.17 $\mathrm{m})$, and the lowest is in the valley of Krivaja on the well 188 ( $89.80 \mathrm{~m})$. However, if we start from north to south, water-tables between the wells 71 and 100 and the well 188 and 231 record a moderate increase, so we can say that general height relations, together with the fact that south of the well 231 the terrain goes down to a lower pleistocene terrace, show that in the analysed profile the general direciton of the output of the phreatic aquifer is from the north to south.

As a rule, the relief significantly influences the variablility of the water-table regime of the aquifer. This means that with the increase of the height of the terrain the depth of the phreatic aquifer generally increases, and with the increase of the depth, mainly because of the decrease of evapotranspiration, the variability of the perennial water-table of the aquifer decreases on average. The mentioned regularity is confirmed by the depth of phreatic aquifers on the 13 wells, according to which the aquifer of the Bačka loess plateau as a 
prominent relief entity in Bačka is situated in the significant depth. The regularity is also confirmed by a small average variability of the phreatic water-table. For example, average annual heights for a 30 -year period fluctuate from $4.90 \mathrm{~m}$ (the wells 71 and 207) to $11.07 \mathrm{~m}$ (the well 97) or on average for all 13 wells, $7.55 \mathrm{~m}$. The amplitudes of average monthly water-tables in the observed period are $14 \mathrm{~cm}$ (the well 142) to $139 \mathrm{~cm}$ (the well 79), which is $55 \mathrm{~cm}$ on average.

It is obvious that within the loess plateau itself, there are significant differences in the depths and especially in the amplitude values of average monthly water-tables of the phreatic aquifer (Table 1). This was expected since the plateau is rather segmented for a flatland plateau in terms of height levels, and more importantly, it has an unsteady morphology. The data show that the depth and variablity of the water-table regime are influenced not only by the height of the well, but also by the microrelief characteristics of the area. Thus, a small depth and at the same time the largest variability of the water-table, although located on the significant heights, have been recorded in the wells located in the depressions, such as river valley and loess valleys (wells 79, 71 and 57). The emphasized variability presents a result of the surface and underground drainage of atmospheric water from the surrounding elevated terrain, as well as the emphasized evapotranspiration.

So we can establish, apart from the three mentioned wells, and partly on the wells 188 and 207 , that in other measurement localities the amplitudes of the average monthly water-tables of the loess plateau are relatively low. However, this is not the case with the differences of the absolute extreme water-tables recorded in the thirty-year period for the wells which have higher values fluctuating from $2.04 \mathrm{~m}$ (the well 61) to $10.98 \mathrm{~m}$ (the well 231). This emphasized difference between the amplitudes of absolute extreme and average monthly water-tables of phreatic underline the fact that the water regime of the phreatic aquifer of the the loess plateau is primarily influenced by the climate, mainly by the slow input of the scarce atmospheric waters in the longer period of time, often in the perennial period as well.

Out of all the physical and geographical factors of the climate conditions, precipitation and air temperature have the greatest influence in the determination of the main characteristics of the water regime of the phreatic aquifer of the Backa loess plateau.

According to the geographical position the investigated area is situated in the region of moderate continental climate (Katić at al., 1979). From the point of view of a small area and climate and insignifi-

Table 1 The relation of the height of the well, average annual depth of the phreatic aquifer and amplitudes of average monthly water-tables of the phreatic aquifer for the period 19511980.

\begin{tabular}{|c|r|r|r|}
\hline Well & Terrain elevation $(\mathbf{m})$ & Depth $(\mathbf{m})$ & Amplitude (cm) \\
\hline 79 & 100.30 & 5.65 & 139 \\
\hline 97 & 112.46 & 11.07 & 26 \\
\hline 41 & 121.74 & 8.57 & 16 \\
\hline 57 & 109.62 & 5.13 & 92 \\
\hline 71 & 105.96 & 4.90 & 102 \\
\hline 100 & 110.14 & 7.73 & 41 \\
\hline 142 & 108.07 & 8.47 & 14 \\
\hline 188 & 97.75 & 7.95 & 81 \\
\hline 231 & 100.02 & 8.48 & 76 \\
\hline 207 & 103.58 & 4.90 & 64 \\
\hline 60 & 106.99 & 6.72 & 33 \\
\hline 61 & 105.69 & 9.27 & 16 \\
\hline 192 & 96.71 & 9.27 & 18 \\
\hline
\end{tabular}

cant vertical diversification of the terrain, within the borderline of the plateau there do not exist prominent temperature differences. For example, average annual air temperatures for a perennial period on the north rim $\left(\right.$ Palić, $\left.10.5^{\circ} \mathrm{C}\right)$ and the south rim (Vrbas, $10.6^{\circ} \mathrm{C}$ ) differ only in $0.1^{\circ} \mathrm{C}$. In addition, the highest values occur in July, and the lowest in January, with a significant annual amplitude of about $22^{\circ} \mathrm{C}$.

Pluviometric regime of the investigated area, as well as of the wider area of the entire Bačka, features the Central-European, specifically the Danube Basin type of precipitation distribution regime which is characterised by a prominently uneven monthly distribution. The maximum appears in summer, and the minimum in spring (Katić, Dunđerov, 1972). According to the values obtained from the measurement wells Palić and Vrbas, on the territory of Bačka loess plateau, annual average of atmospheric drainage is about $550 \mathrm{~mm}$. In addition to the underground drainage of water from neighbouring areas, the precipitation represents the main source of input of the phreatic aquifer in the investigated area. But, it is very hard to determine the effective quantity of precipitation which reaches the aquifer. This is due to a fact, that the quantity depends on a number of factors, such as: relief energy, the characteristics of the soil and vegetation, the quantity and the form of precipitation, the values of other climate elements, etc. For example, according to M. Stojšić (1994), on the territory of Bačka only due to the surface drainage of precipitation, the loss in the input of the aquifer is $10.9 \%$ on the annual average. Within the borderline of the investigated area, where the relief energy is higher than the average for the entire Bačka, the level of the surface drainage is slightly higher.
Apart form precipitation, which only generally determines the water regime of the phreatic aquifer, a large influence on its characteristics comes from the processes of evaporation and evapotranspiration. With precipitation, these processes form so-called vertical climate factors of the water-table. Since the biggest part of the Bačka loess plateau is covered with vegetation, special attention should be given to evapotranspiration. It is a very complex process which, among other things, depends on the climate conditions of the soil, as well as of the plants. This makes it more difficult to determine the exact level of evapotranspiration, so a lot of different calculation methods are used as a basis for the so-called potential evapotranspiration which is usually higher than the reality. According to the data in Table 2, average monthly values of evapotranspiration in the perennial period for the meteorological stations of Palić and Vrbas, calculated by the Türc formula, are the highest in summer months with the maximum in July, and the lowest in January. ${ }^{2}$

The difference between the monthly precipitation total and the values of the potential evapotranspiration is called the water balance of the climate factors (Škorić, Stojšić, 1996). Since the values of the potential evapotranspiration are higher than the real ones, even during a period of seven months (April - October) in a year, the values of the water balance of the climate factors are negative, which results in a negative average annual value (Table 2). But, although the obtained values of the water

\footnotetext{
Because of the negative average monthly air temperatures, with the application of the Türc formula, we obtain negative values of evapotranspiration. Since this is not possible, the value of this parametre is shown as zero.
} 
Table 2 Average monthly and average annual values of the precipitation total (P), the quantity of evapotranspiration $(E)$ and the water balance of the climate factors (K) for m.s. Palic and Vrbas in the period 1951-1970

\begin{tabular}{|l|c|c|c|c|c|c|c|c|c|c|c|c|c|}
\hline & I & II & III & IV & V & VI & VII & VIII & IX & X & XI & XII & Annual \\
\hline P $\mathbf{~ m m}$ & 36 & 39 & 31 & 45 & 55 & 70 & 62 & 46 & 37 & 28 & 52 & 56 & 557 \\
\hline $\mathbf{E ~} \mathbf{~ m m}$ & 0 & 1 & 23 & 75 & 105 & 132 & 142 & 122 & 87 & 43 & 15 & 2 & 747 \\
\hline $\mathbf{K ~} \mathbf{~ m m}$ & 36 & 38 & 8 & -30 & -50 & -62 & -80 & -76 & -50 & -15 & 37 & 54 & -190 \\
\hline
\end{tabular}

balance of the climate factors do not reflect the real state of affairs, the obtained results show the approximate annual flow of this very important parametres, which to the largest extent determine the character of the water regime of the phreatic aquifer of the Bačka loess plateau.

In the Graph 3 we can clearly spot the dependency of the annual fluctuation of the water-table of the phreatic aquifer on the annual fluctuation of water balance of the climate factors which are in the specific phaseal discrepancy. In the perennial average, maximum and minimal water-tables of the aquifer come five or six months after maximum or minimun values of the water balance of the climate factors.

\section{Water regime of the phreatic aquifer and the drainage direction}

Considering the scope of influence of the dominant factors on the water regime of the phreatic aquifer of the investigated area, we can say that the processes of input and output of water are, above all, determined by the dominant climate conditions. So, according to the criterion of the influence of dominant factors on the water regime of the phreatic aquifer of the Bačka loess plateau, it belongs to the so-called climate type. This statement can also be confirmed by the analysis of the Graph 4 according to which the maximum average monthly water-table of the aquifer in all 13 wells appears in June and May, i.e. after winter period of the favourable water balance of the climate factors. On the other hand, the lowest average monthly water-tables usually come in November and December as a result of the months with negative water balance of the climate factors present during the entire vegetation period.

It is also important to notice that the extreme values of the average monthly water-tables have the same discrepancy in comparison to the average annual levels of the phreatic aquifer for the perennial period. In June, the maximum level is higher for $24 \mathrm{~cm}$, and in November the minimum is lower for $21 \mathrm{~cm}$ from the average annual water-table of the phreatic aquifer for all the analysed wells. The obtained values show that the average annual fluctuation of water-tables of the phreatic aquifer of the Bačka loess plateau is only 45 $\mathrm{cm}$. Taking into consideration this information, we can say that in relation to the scope of variability, the water regime of the phreatic aquifer of the investigated area belongs to the so-called moderate type. In addition to the climate conditions of dominant sedation of the regime, the contributing factor is to a large extent a significant depth of the aquifer in the Bačka loess plateau as prominent morphological entity in Bačka in terms of height.

Observing the horizontal movement, i.e. the direction of drainage of the phreatic aquifer of the investigated area, it is important to bear in mind the general incline of the entire Bačka towards the east, or south-east. Having in mind local basis (smaller streams, lakes, depressions, etc.), all phreatic waters of Bačka generally drain in the direction of the Danube or the Tisza. The problem of distinguishing the borderlines of the underground drainage in Bačka has been dealt with by, among others, $\mathrm{S}$.
Nanbatić (1968) and M. Dedić and Đ. Božić (1998). Based on the results of the mentioned authors, the water borderline between the underground catchment area of the Danube and the Tisza divides the territory of the Bačka loess plateau on two completely different parts. The water borderline generally stretches along the state border Bajmok - Sivac where it can established that only far west of the plateau is drained towards the Danube, whereas the largest part of the investigated area belongs to the catchment area of the Tisza (Map 3).

The detailed analysis of Map 4, based on the map given in the Regional Area Plan of the SAP of Vojvodina (1974), we can see that the whole central and eastern part of Bačka loess plateau is drained towards the southeast, i.e. directly to the Tisza river, but also

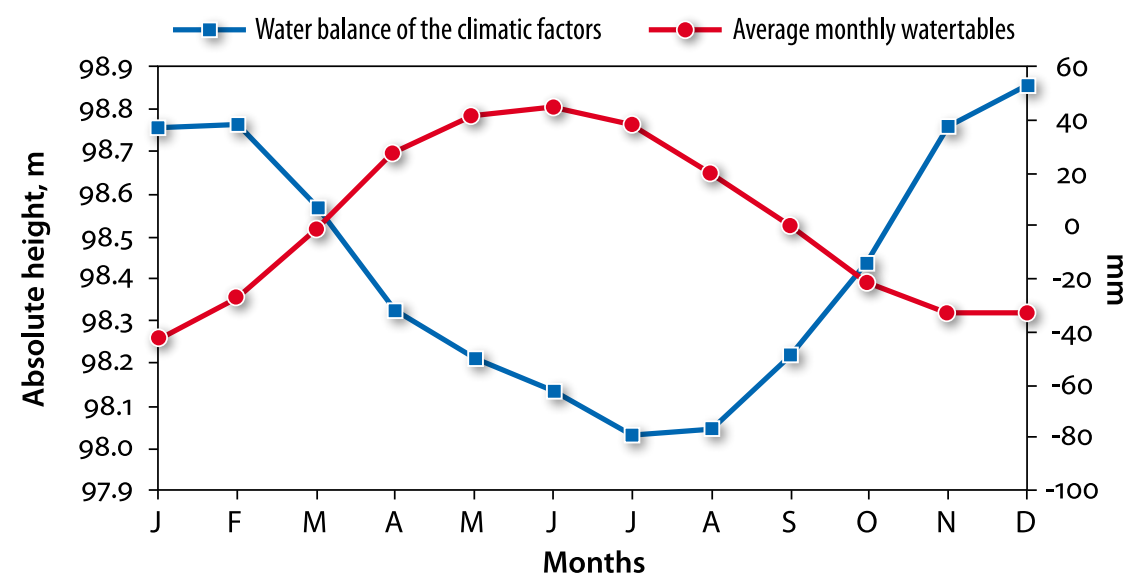

Graph 3 The relation of the average monthly values of the water balance of the climate factors and average monthly water-tables of the phreatic aquifer of the Bačka loess plateau in the period 1951-1970

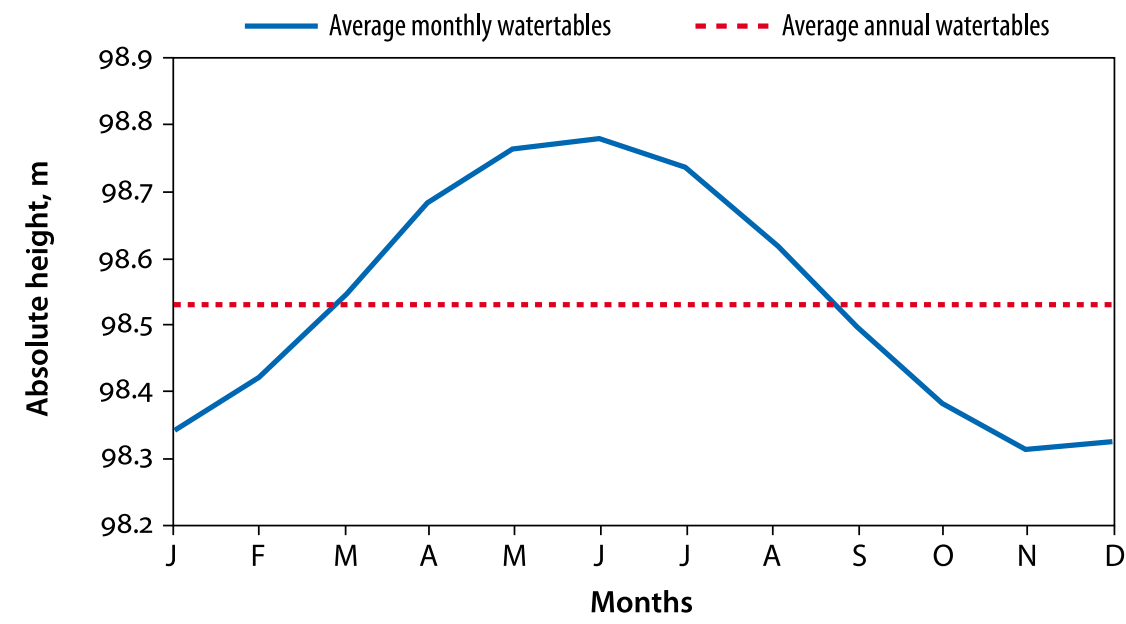

Graph 4 Values of the average monthly water-tables and average values of the average annual water-tables of the phreatic aquifer $(\mathrm{m})$ in the 13 wells on the Bačka loess plateau in the period 1951-1980 
towards the south to the river Jegrička which represents the right tributary of the Tisza.

\section{Conclusion}

In the formation of the main characteristics of the water regime of the phreatic aquifer of the Bačka loess plateau, the main role is given to the physical and geographical factors. Among them, special emphasis is on the climate conditions, i.e. the precipitation quantity and air temperature, followed by the geomorphological relations.

In relation to the dominant factor within the borderline of the invesitigated area, the climate type of the water regime is established, whereas in the relation of the scope of oscillations of the phreatic water-table, the regime belongs to the moderate type. As in the earlier research (S. Marković, 1996; D. Pavić, 2006), this time the rule has also been proven confirming that the phreatic aquifer of the climate type is characterised by small annual oscillations of the aquifer level in the perennial average, but with the emphasized amplitudes of the absolute extreme water-tables.

Taking into consideration the general incline of the terrain and shallow geological layers, the largest part of Bačka loess plateau has underground drainage directly or indirectly towards the river Tisza. Only in the far western part of the investigated area, part of the western state borderline Bajmok-Sivac, its underground drainage is towards the Danube.

\section{Acknowledgements}

This work is supported by the Ministry of science and nature protection, Republic of Serbia (grant 146019).

\section{References}

Bukurov, B. 1975. Fizičko-geografski problemi Bačke. SANU - Odeljenje prirodno- matematičkih nauka, knjiga 43 , Beograd, 209 pp..

Dedić, M., Božić, Đ. 1998. Režim voda područja omeđenog Dunavom i Mostongom. Monografija: Mostonga i vode $\mathrm{Za}-$ padne Bačke, PČESA, Edicija Tija voda: 23-32.

Katić, P., Dunđerov, N. 1972. Raspodela padavina u Vojvodini. Zbornik Matice srpske za prirodne nauke 42: 117-124

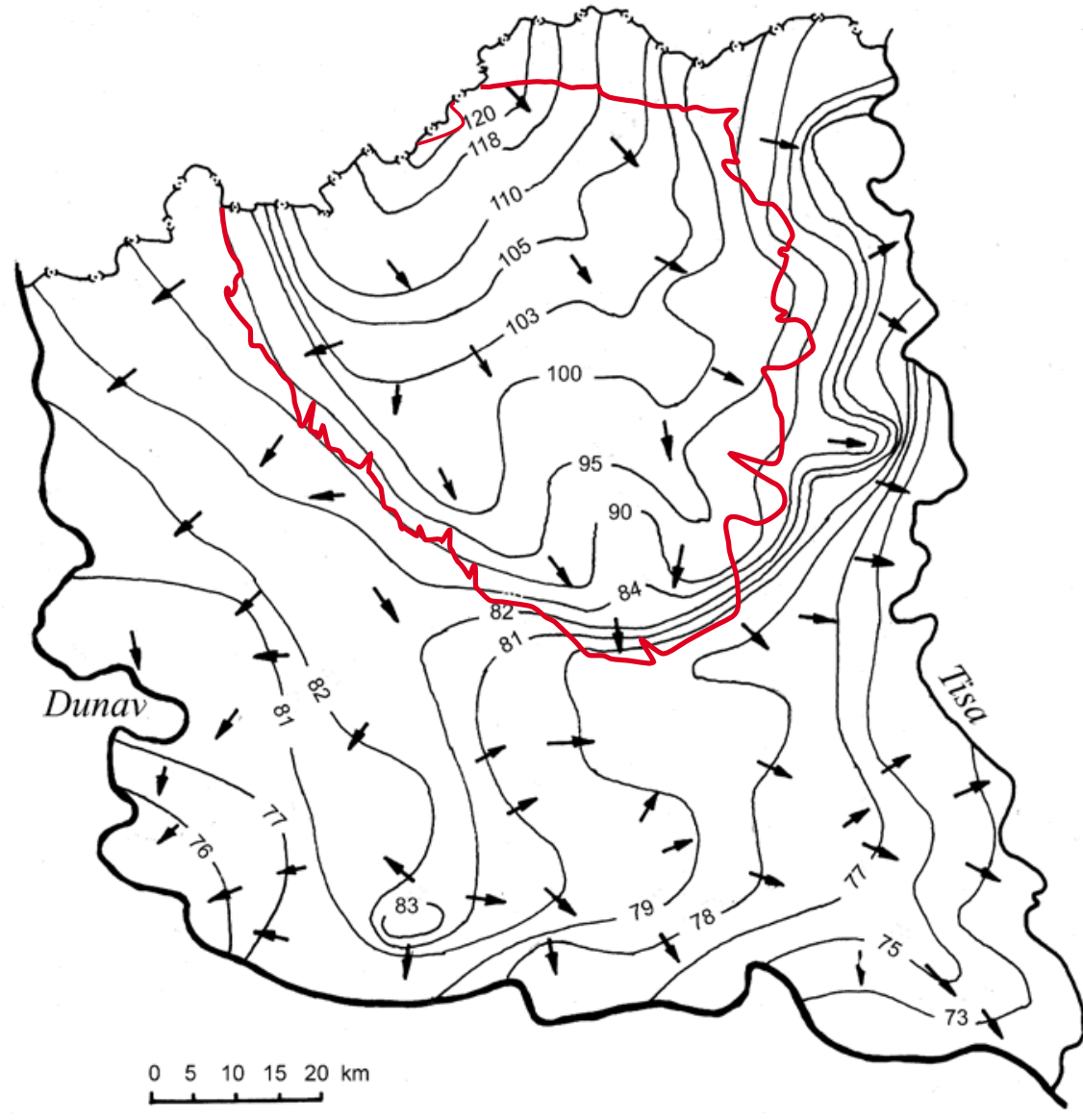

Map 3 The drainage direction of the phreatic aquifer

Katić, P. at al. 1979. Klima Vojvodine. Poljoprivredni fakultet, Institut za ratarstvo i povrtarstvo, Novi Sad.

Marković, S. 1996. Vodni režim i pravci oticanja freatske izdani u jugoslovenskom delu Banata. Monografija, PMF, Institut za geografiju, Novi Sad.

Marković, S., Bogdanović, Ž. 1995. Uticaj reljefa na vodni režim freatske izdani u Banatu. Zbornik radova Instituta za geografiju 25: 11-20.

Nanbatić, S. 1961. Podzemne vode u AP Vojvodini. Glasnik Saveza vodnih zajednica NR Srbije 29-30: 3-12

Pavić, D. 2006. Vodni režim i pravci oticanja freatske izdani Bačke. Monografija, PMF, Departman za geografiju, turizam i hotelijerstvo, Novi Sad.

Stojšić, M. 1968. Pojava suvišnih unutrašnjih voda na ravničarskom delu Vojvodine. Poljoprivredni fakultet, Novi Sad.
Stojšić, M. 1994. Režimi i bilansi atmosferskih i površinskih voda u Vojvodini. Zbornik radova sa savetovanja: "Voda, zemljište i agrikulturna hemija": 16-27

Stojšić, M. 1994. Režimi i bilansi podzemnih voda u Vojvodini, Zbornik radova sa savetovanja: "Voda, zemljište i agrikulturna hemija": 28-37

Dnevnici osmatranja dubine freatske izdani u Vojvodini (1951 - 1980), JVP "Vode Vojvodine", Novi Sad.

Meteorološki godišnjaci (1961-1980), RHMZ, Beograd.

Regionalni prostorni plan SAP Vojvodine (1974), Pokrajinski zavod za urbanizam i komunalno-stambena pitanja, Novi Sad.

Topografska karta (1984): R 1:25.0oo, Vojnogeografski institut, Beograd.

Topografska karta (1983): R 1:50.0oo, Vojnogeografski institut, Beograd. 